\title{
Electrochemical Study of Some Substituted Chromene Derivatives in Nonaqueous Media at Pt, Au and Glassy Carbon Electrodes
}

\author{
A.A. El Maghraby*
}

Chemistry Department, Faculty of Science, Cairo University, Giza, Egypt

\begin{abstract}
The redox characteristics of some substituted chromene derivatives has been investigated in different nonaqueous solvents such as, 1,2- dichloroethane (DCE), dichloromethane (DCM) and acetonitrile (AN) using $0.1 \mathrm{~mol} \mathrm{dm}^{-3}$ tetrabutylammonium perchlorate (TBAP) as a supporting electrolyte at platinum, gold and glassy carbon electrodes, using cyclic voltammetry. Through controlled potential electrolysis (CPE), the product of oxidation and reduction can be separated and identified. The product of oxidation was found to be the corresponding bis-compound. On the other hand, the reduction occurs in a single two electron process to give the dianion, which abstracts protons to saturate the $(-\mathrm{C}=\mathrm{O})$ bond. The effect of substituents on the redox mode of an electroactive site has also been studied.
\end{abstract}

Keywords: Chromene, cyclic voltammetry, oxidation, reduction, non-aqueous solvent, platinum electrode, glassy carbon electrode, gold electrode.

\section{INTRODUCTION}

The electrochemistry of heterocyclic compounds with nitrogen heteroatom has been extensively studied [1-9]. In spite of great importance and wide uses of the heterocyclic aromatic compounds with oxygen or sulphur atoms, it is rare to find an attempt to study their electrochemical redox characteristics. For this reason, it was found worthwhile to review this work dealing with the electrochemical redox characteristics of some 4-substituted 2-amino-7,7-dimethyl-5oxo-5,6,7,8-tetrahydro-4H-chromone-3-carbonitrile derivatives (1a-e).<smiles>[X]c1ccc(C2C(C#N)=C(N)OC3=C2C(=O)CC(C)(C)C3)cc1</smiles>
a, $\mathrm{X}=\mathrm{H}$
$\mathrm{b}, \mathrm{X}=\mathrm{Br}$
c, $\mathrm{X}=\mathrm{Cl}$
$\mathrm{d}, \mathrm{X}=\mathrm{OCH}_{3}$
$\mathrm{e}, \mathrm{X}=\mathrm{NO}_{2}$

These compounds were extensively studied using cyclic voltammetry in dichloromethane (DCM), 1,2-Dichloroethane (DCE), and acetonitrile (AN) on platinum, gold and glassycarbon electrodes. The number of electrons participating in each electrode process was determined using coulometric technique. Separation and identification of the final products

*Address correspondence to this author at the Chemistry Department, Faculty of Science, Cairo University, Giza, Egypt;

E-mail:maghraby04@yahoo.com of both oxidation and reduction process were made through the controlled potential electrolysis.

\section{MATERIALS AND METHODOLOGY}

The organic compounds were synthesized according to the procedures outlined in the literature [10]. All the synthesized compounds were purified by repeated crystallization. dried under reduced pressure and the purity was checked by thin layer chromatography.

Electrochemical measurements, including cyclic voltammetry, coulometry, and controlled potential electrolysis, were carried out using the following apparatus: The EG\&G Princeton applied research model 283 Potentiostat/Galvanostat controlled from a PS-486-Dx microcomputer via a National Instrument IEEE-488 through GPIB board by means of M270/250 program was used for the electrochemical control.

All measurements were carried out with $2.5 \times 10^{-4} \mathrm{~mol}$ of the reactant in $15 \mathrm{ml}$ dry oxygen-free solvent with $0.1 \mathrm{~mol}$ $\mathrm{dm}^{-3}$ tetra- $n$-butylammonium perchlorate as supporting electrolyte. Dichloromethane (DCM), 1,2-Dichloroethane (DCE), and acetonitrile (AN) were used as solvents. During the solvent purification, all the processes were performed under a dry oxygen-free argon atmosphere. Fractionation was carried out using a $120 \mathrm{~cm}$ column filled with glass spirals at a reflux ratio of 50:1. All the purified solvents were stored under argon in the dark. Purification of different solvents was carried out according to the literature $[7,11,12]$.

Supporting electrolyte, tetra- $n$-butyl ammonium perchlorate (TBAP), was purified by consecutive crystallization from ethanol/water $(9: 1, \mathrm{v}: \mathrm{v})$ and dried before use.

The working electrodes were $\mathrm{Pt}\left(0.00785 \mathrm{~cm}^{2}\right)$, glassy carbon $\left(0.00785 \mathrm{~cm}^{2}\right)$ or $\mathrm{Au}\left(0.00375 \mathrm{~cm}^{2}\right)$ electrode, and the auxiliary electrode was $\mathrm{Pt}$ wire immersed in the corresponding electrolyte. The reference electrode was $\mathrm{Ag} / \mathrm{AgCl} / \mathrm{Cl}^{-}$ (sat. $A N)$ and the potential $\left(E_{P}\right)$ values are referred to the redox potential of ferrocenium/ferrocene system [13]. 


\subsection{Controlled Potential Electrolysis (CPE)}

CPE experiments were carried out in dry acetonitrile containing 0.1 mol.dm ${ }^{-3}$ tetra- $n$-butylammonium perchlorate (TBAP) as supporting electrolyte. The potential was controlled at the current plateau of the oxidation or reduction peaks $\left(300 \mathrm{mV}\right.$, more positive or more negative than the $E_{P}$ in oxidation and reduction processes, respectively). As a working electrode, a platinum gauze anode $\left(c a .80 \mathrm{~cm}^{2}\right)$ was used. The progress of the electrolysis was followed by periodically recording the decrease in peak current with time. From time to time, the working Pt gauze electrode was removed from the cell, sprayed with pure acetone and burned in a direct flame, cooled and replaced in the cell. After the completion of electrolysis, the cell was disconnected from the circuit and the solvent was evaporated in the vacuum. The residue was shaken with dry ether and the supporting electrolyte was filtered off. The ethereal layer was evaporated in turn. The obtained residue was chromatographed on thin layer silica gel plates using chloroform as an eluent. The main oxidation product of $\mathbf{1 a}$ obtained was scraped off the plate and extracted with acetonitrile, filtered and evaporated in vacuum.

\section{Oxidation Product of 1 a}

The resulting solid compound was identified as biscompound (m.p. $285^{\circ} \mathrm{C}$ ), (yield $72 \%$ ). Anal. Calcd: C, H, N. Found: C, H, N. The ${ }^{1} \mathrm{H}$ NMR (DMSO, TMS) spectrum of 1a:- $\delta$ 7.95-7.85 (m, 2H, 2NH), 7.52-7.13 (m, 10H, Ar-H); 4.25-4.20 (m, 2H, 2CH), 2.76-2.62 (m, 4H, 2CH $), 1.91-1.82$ $\left(\mathrm{m}, 4 \mathrm{H}, 2 \mathrm{CH}_{2}\right), 1.14-1.10\left(\mathrm{~m}, 12 \mathrm{H}, 4-\mathrm{CH}_{3}\right) \mathrm{ppm}$. As shown from the results of ${ }^{1} \mathrm{H} \mathrm{NMR}$, the disappearance of the charac- teristic signal corresponding to $\mathrm{NH}_{2}$ protons at $\delta=6.90 \mathrm{ppm}$, whereas the appearance of two signals corresponding to two $-\mathrm{NH}$ protons at $\delta=7.95-7.85 \mathrm{ppm}$, which are lost after $\mathrm{D}_{2} \mathrm{O}$ exchange. Mass spectrum: shows the main fragments at $\mathrm{m} / \mathrm{z}$ 586, parent; $293\left(\mathrm{M}^{+} / 2\right), 267\left(\mathrm{M}^{+}-\mathrm{CN}\right), 215\left(\mathrm{M}^{+}-\mathrm{NC}-\mathrm{C}=\mathrm{C}-\right.$ $\left.\mathrm{NH}_{2}\right), 138\left(\mathrm{M}^{+}-\mathrm{C}_{6} \mathrm{H}_{5}\right), 110(-\mathrm{C}=\mathrm{O}), 68\left(-\mathrm{C}-\left(\mathrm{CH}_{3}\right) 2\right)$.

\section{Reduction Product of 1 a}

The resulting solid has (m.p. $264^{\circ} \mathrm{C}$ ), (yield $60 \%$ ). Anal. Calcd: C,72.97; H,6.76; N, 9.46. Found: C,72.82; H,6.71; $\mathrm{N}, 9.32$; the IR spectrum $(\mathrm{KBr})$ is characterized by the disappearance of the band $1680 \mathrm{~cm}^{-1}(\mathrm{C}=\mathrm{O})$ in comparison with that obtained for the original compound 1a. The ${ }^{1} \mathrm{H}$ NMR (DMSO, TMS) spectrum of $\mathbf{1 a}:-\delta=11.1(\mathrm{~s}, \mathrm{br}, 1 \mathrm{H}, \mathrm{OH}), 8.4$ (s, 1H, CH), 7.52-7.13 (m, 5H, Ar-H); 6.9 (m, 2H, $\left.\mathrm{NH}_{2}\right), 4.2$ (s, 1H, CH), 2.75-2.6 (br, $2 \mathrm{H}, \mathrm{CH}_{2}$ ), 1.90-1.81 (br, $2 \mathrm{H}, \mathrm{CH}_{2}$ ), 1.14-1.10 $\left(\mathrm{m}, 6 \mathrm{H}, 2 \mathrm{CH}_{3}\right) \mathrm{ppm}$. As shown from the results of ${ }^{1} \mathrm{H}$ NMR, the appearance of the characteristic signals corresponding to the proton of the $(\mathrm{OH})$ at $\delta=11.1$. Mass spectrum: shows the main fragments at $\mathrm{m} / \mathrm{z} 296$; parent; 270 $\left(\mathrm{M}^{+}-\mathrm{CN}\right) ; 218\left(\mathrm{M}^{+}-\mathrm{NC}-\mathrm{C}=\mathrm{C}-\mathrm{NH}_{2}\right) ; 141\left(\mathrm{M}^{+}-\mathrm{C}_{6} \mathrm{H}_{5}\right) ; 113(-$ $\mathrm{C}=\mathrm{O}), 71\left(-\mathrm{C}-\left(\mathrm{CH}_{3}\right) 2\right)$.

\section{RESULTS AND DISCUSSION}

To study the effect of the substituents on the redox mode and the electrochemical characteristics of the investigated compounds 1a-e, all measurements were carried out in dichloromethane (DCM), 1,2-Dichloroethane (DCE), and acetonitrile (AN) as solvents, using tetra- $n$-butyl ammonium perchlorate (TBAP) as a supporting electrolyte $\left(0.1 \mathrm{~mol} . \mathrm{dm}^{-3}\right)$, at $25^{\circ} \mathrm{C}$ at platinum, gold and glassy-carbon electrodes. The

Table 1. The Voltammetric Data of Compounds (1a-e)

\begin{tabular}{|c|c|c|c|c|c|c|c|}
\hline \multirow{3}{*}{ Compd } & \multirow{3}{*}{ Electrode } & \multicolumn{2}{|c|}{$\mathbf{A N}$} & \multicolumn{2}{|c|}{ DCE } & \multicolumn{2}{|c|}{ DCM } \\
\hline & & \multicolumn{2}{|c|}{ D.N. 14.1} & \multicolumn{2}{|c|}{0.100} & \multicolumn{2}{|c|}{1.00} \\
\hline & & $E_{P}^{R}$ & $E_{P}^{O}$ & $E_{P}^{R}$ & $E_{P}^{O}$ & $E_{P}^{R}$ & $E_{P}^{O}$ \\
\hline $1 \mathrm{a}$ & $\mathrm{Pt}$ & -1620 & 1355 & -2073 & 1593 & -1878 & 1648 \\
\hline \multirow{2}{*}{$\sigma=0$} & GC & -2215 & 1371 & -2184 & 1593 & -2200 & 1593 \\
\hline & $\mathrm{Au}$ & -2267 & 1787 & -1716 & 1522 & -2184 & 1537 \\
\hline $1 \mathrm{~b}$ & $\mathrm{Pt}$ & -1934 & 1426 & -1740 & 1565 & -1620 & 1569 \\
\hline \multirow{2}{*}{$\sigma=0.23$} & GC & -2225 & 1371 & -2227 & 1593 & -2267 & 1648 \\
\hline & $\mathrm{Au}$ & -2040 & 1410 & -1763 & 1521 & -2240 & 1648 \\
\hline $1 \mathrm{c}$ & $\mathrm{Pt}$ & -1823 & 1482 & -1551 & 1604 & -1668 & 1569 \\
\hline \multirow{2}{*}{$\sigma=0.23$} & GC & -2185 & 1427 & -2156 & 1565 & -1958 & 1565 \\
\hline & $\mathrm{Au}$ & -2184 & 1482 & -2045 & 1537 & -2267 & 1593 \\
\hline 1d & $\mathrm{Pt}$ & -1684 & 1371 & -2017 & 1565 & -1767 & 1565 \\
\hline \multirow{2}{*}{$\sigma=-0.27$} & $\mathrm{GC}$ & -2209 & 1366 & -2165 & 1537 & -2128 & 1537 \\
\hline & $\mathrm{Au}$ & -2203 & 1360 & 1906 & 1287 & -1906 & 1565 \\
\hline $1 \mathrm{e}^{*}$ & $\mathrm{Pt}$ & -1782 & 940 & -1716 & 1093 & -1535 & 1055 \\
\hline \multirow{2}{*}{$\sigma=0.78$} & $\mathrm{GC}$ & -1764 & 960 & -1740 & 1117 & -1459 & 1055 \\
\hline & $\mathrm{Au}$ & -1840 & 1226 & -1716 & 998 & -1763 & 1379 \\
\hline
\end{tabular}

* There are another peaks with $\mathrm{E}_{\mathrm{p}}=-1360 \mathrm{mV}(\mathrm{AN}) ; \mathrm{Ep}=-1304 \mathrm{mV}(\mathrm{DCE})$ and $\mathrm{Ep}=-1420 \mathrm{mV}(\mathrm{DCM})$. 


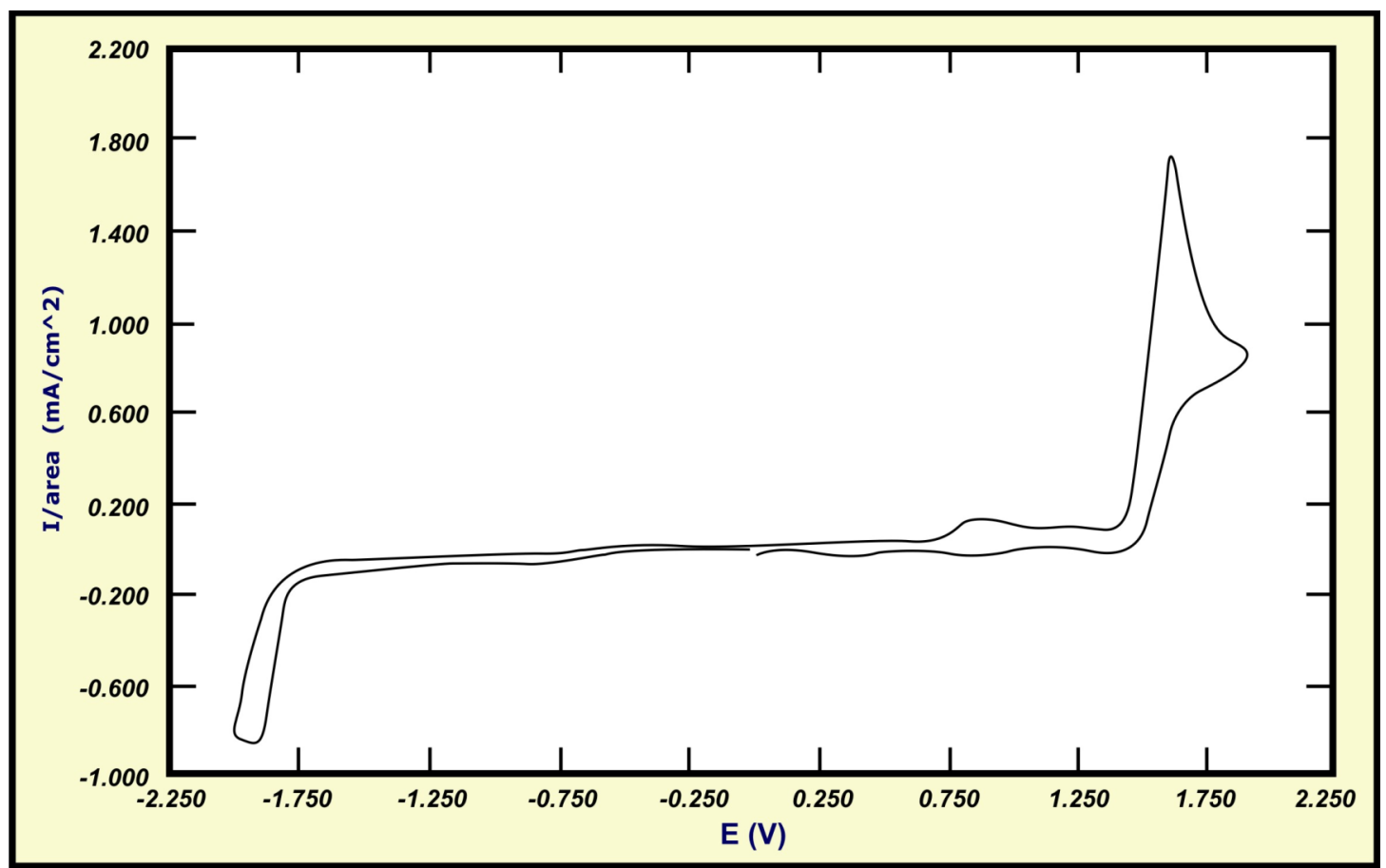

Fig. (1). Cyclic voltammogram of compound $1 \mathrm{c}$ in An at glassy carbon $(\mathrm{GC})$ electrode $\left(\mathrm{Scan}\right.$ rate $\left.=100 \mathrm{mV} / \mathrm{s} ; \mathrm{T}=25^{\circ} \mathrm{C}\right)$.

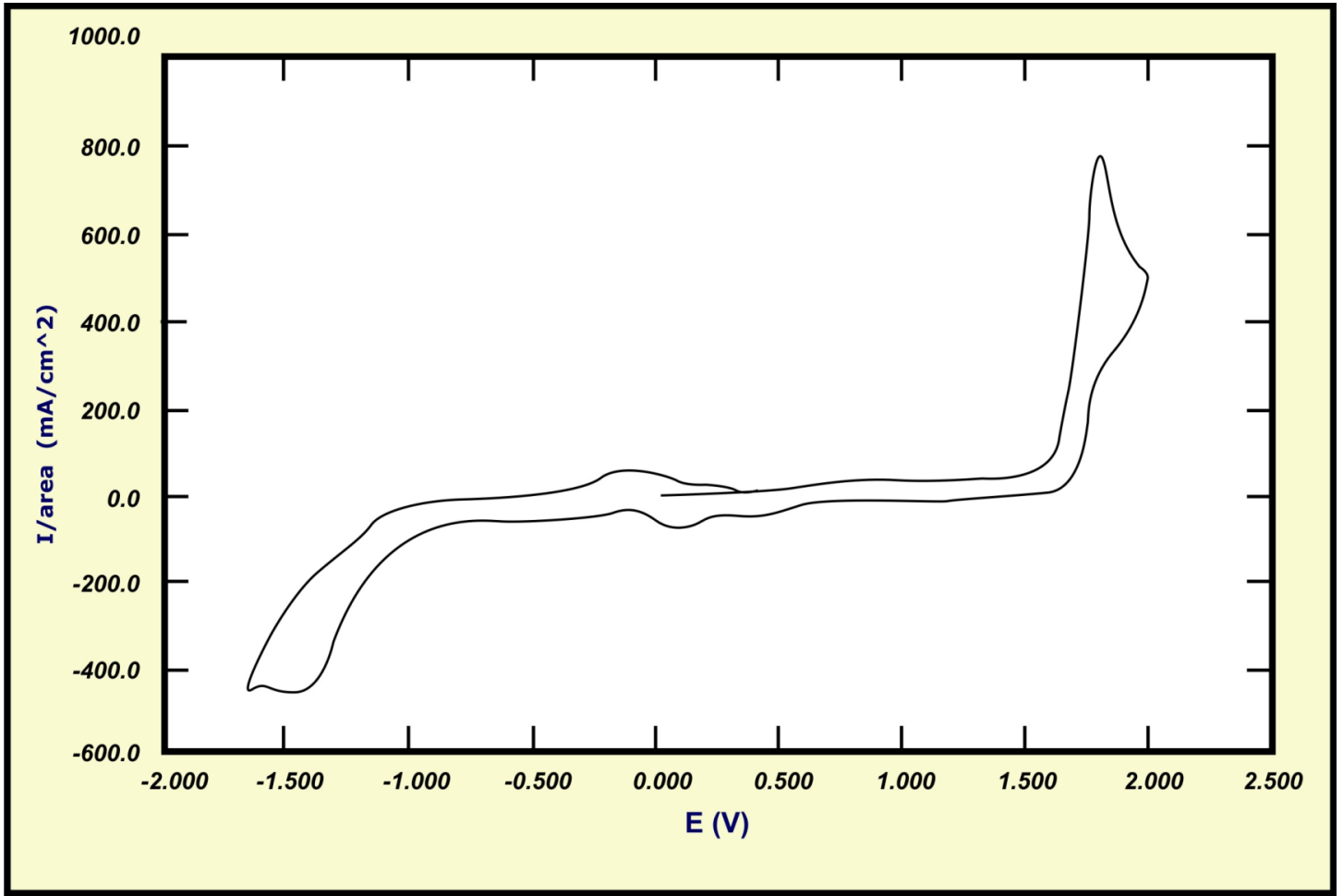

Fig. (2). Cyclic voltammogram of compound $1 \mathrm{~b}$ in DCE at Pt-electrode (Scan rate $\left.=100 \mathrm{mV} / \mathrm{s} ; \mathrm{T}=25^{\circ} \mathrm{C}\right)$.

data are summarized in Table 1. An example of the cyclic voltammograms of the investigated compounds is shown in Figs. (1, 2).

From the data obtained in Table 1, from the shape of the cyclic voltammograms, and also from the results of the coulometric measurements, and the isolation and identification of the controlled potential electrolysis products, it was evident that all compounds were oxidized in a single irreversi- ble one electron process following the well known pattern of EC-mechanism at potential almost the same as that of the first oxidation wave of primary aromatic amine $\left(-\mathrm{NH}_{2}\right)$ [14]. They were oxidized through one electron loss to give the radical-cation, which lost one proton to give the corresponding $(-\mathrm{NH})$ radical. The formed radical undergoes a dimerization reaction to give the $(\mathrm{E}-\mathrm{E})$ form of the bis- compound (Scheme 1). 


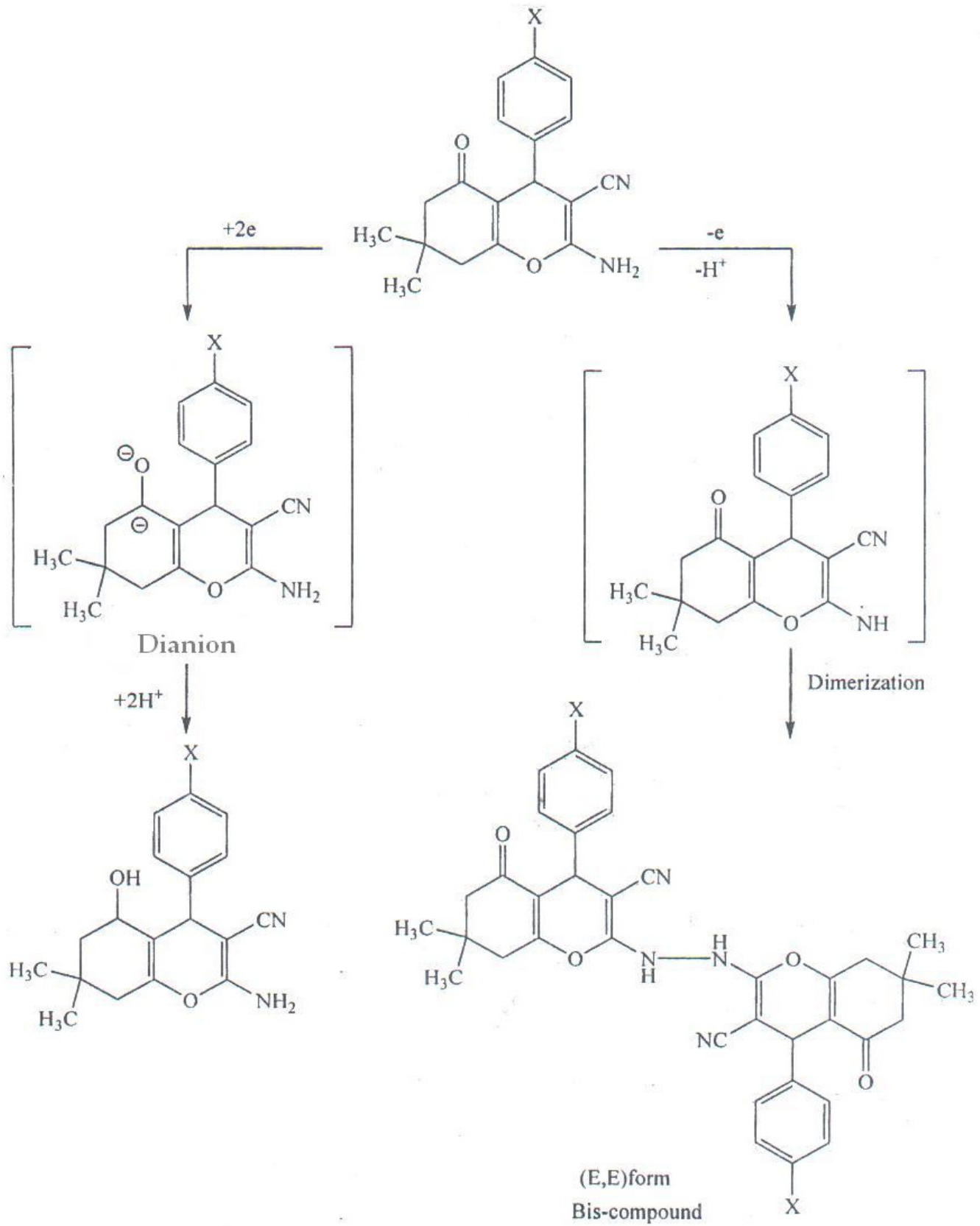

Scheme 1.

On the other hand, these compounds were reduced in a single irreversible two electron reduction process to give the dianion, which is a strong basic enough to abstract two protons from the media to saturate the $(-\mathrm{C}=\mathrm{O})$ bond [15-18]. Compound 1e displayed another second reduction wave, as well, which is characteristic for the reduction of the attached aromatic nitro group [19-21].

The effect of substituents on both oxidation and reduction of an electroactive site can be illustrated by applying the wellknown modified Hammett equation (1) of the form [22-24].

$\mathrm{E}_{\mathrm{P}}^{*}=\rho_{\mathrm{x}} \sigma_{\mathrm{x}}+E_{P}^{H}$

where, $\sigma_{\mathrm{x}}$ is the Hammett constant, $\rho_{\mathrm{x}}$ is the polarographic reduction or oxidation constant, and $\mathrm{E}_{\mathrm{P}}^{*}, E_{P}^{H}$ are the peak potentials of the substituted and unsubstituted compounds, respectively. Fig. (3) illustrates Hammett equation correlations of the peak potentials 1a-e for both oxidation and reduction processes.

It is obvious from the equations Table $\mathbf{2}$, that the magnitude of both oxidation and reduction constants $\rho_{\mathrm{x}}{ }^{\mathrm{Ox}}$ and $\rho_{\mathrm{x}}{ }^{\mathrm{Red}}$ are almost the same. This indicates that the resonance interaction between the substituent and both reduction and oxidation centre in the molecule are almost equal.

All the investigated compounds behave similarly by using three monoaqueous solvents (DCM, DCE, and AN). A linear relation between $\Delta \mathrm{E}_{\mathrm{P}}$ and the doner number of the solvent [25] is obtained Fig. (4). 

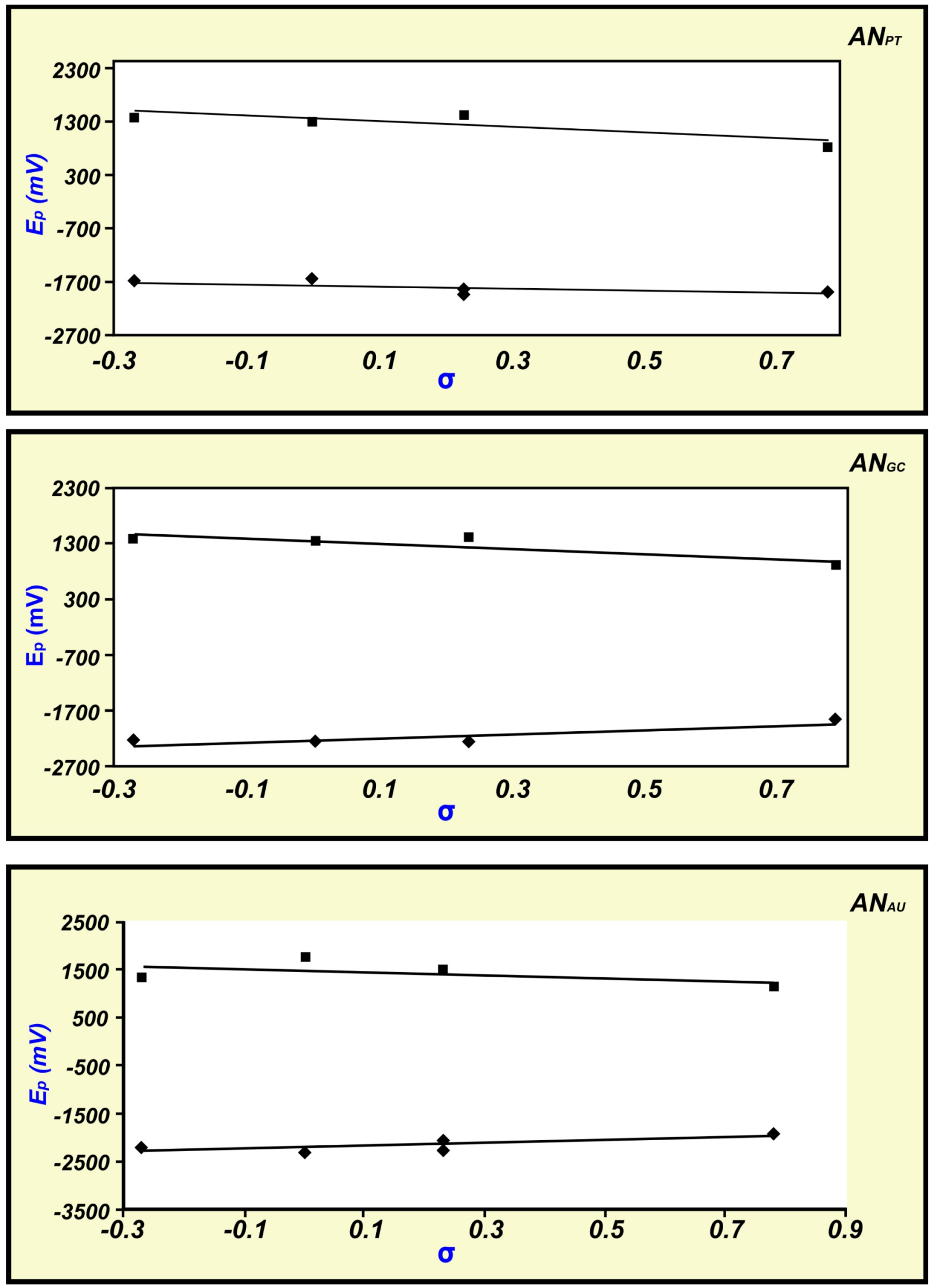

Fig. (3). Dependence of $E_{P}^{O}$ and $E_{P}^{R}$ of compounds (1a-e) in AN on Hammett substitution constant.( $\sigma$ ) at platinum, glassy carbon and gold electrodes. 


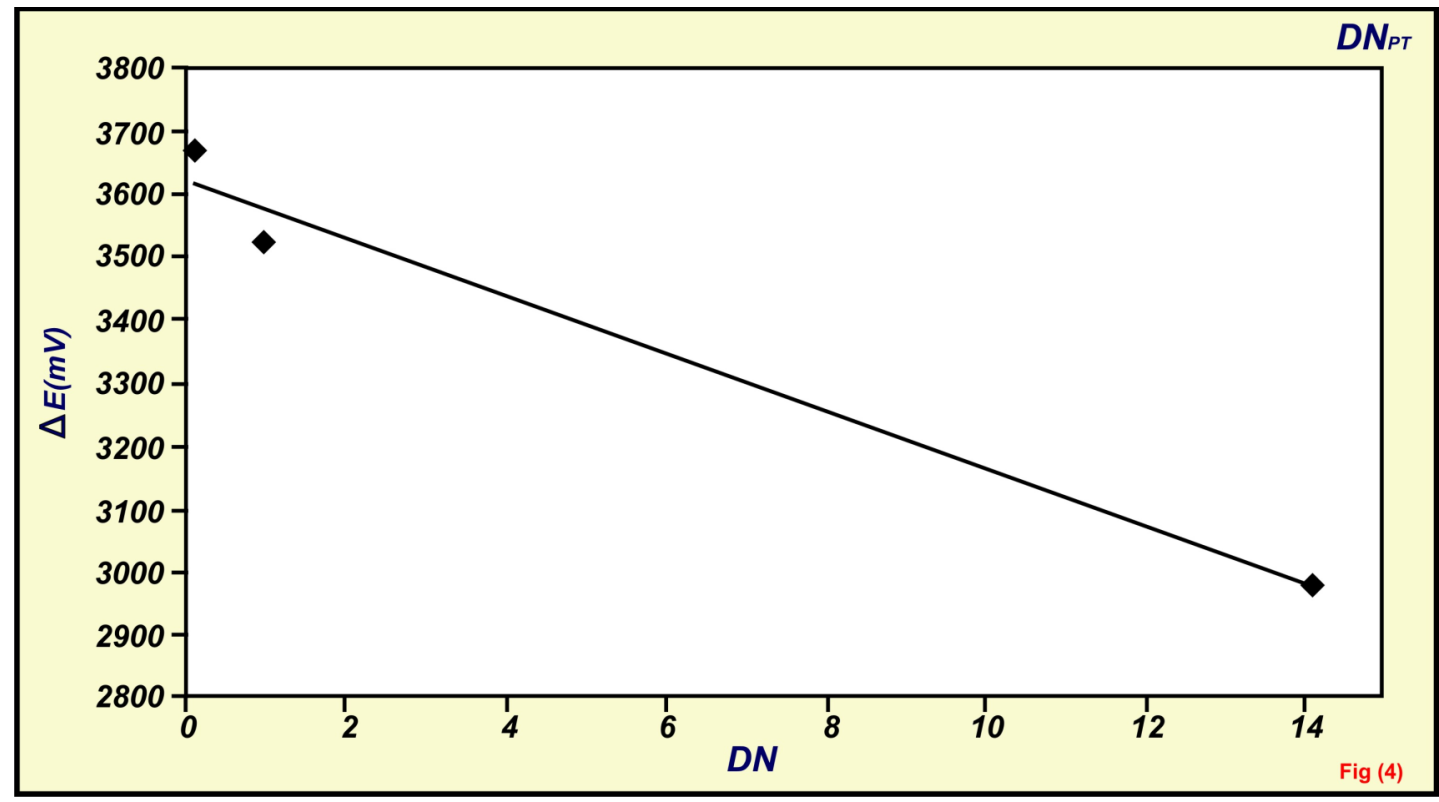

Fig. (4). Dependence of $\triangle E_{p}=\left(E_{p}{ }^{O}-E_{p}{ }^{R}\right)$ of compound 1a on the donor number (DN) of the solvents.

Table 2. Hammett Correlation of Compounds (1a-e) in DCM, DCE and AN

\begin{tabular}{|c|c|c|}
\hline \multirow{2}{*}{ Solvent (WE) } & \multicolumn{2}{|c|}{$\sigma-\mathbf{E}_{\mathbf{P}}(\mathbf{v})$ Plot equ. } \\
\cline { 2 - 3 } & Reduction & Oxidation \\
\hline \hline $\mathrm{DCM}(\mathrm{Pt})$ & $E_{P}^{R}=0.277 \sigma_{\mathrm{x}}-1.748$ & $E_{P}^{O}=-0.542 \sigma_{\mathrm{x}}+1.596$ \\
\hline $\mathrm{DCM}(\mathrm{GC})$ & $E_{P}^{R}=0.68 \sigma_{\mathrm{x}}-2.134$ & $E_{P}^{O}=-0.481 \sigma_{\mathrm{x}}+1.573$ \\
\hline $\mathrm{DCM}(\mathrm{Au})$ & $E_{P}^{R}=0.188 \sigma_{\mathrm{x}}-2.109$ & $E_{P}^{O}=-0.166 \sigma_{\mathrm{x}}+1.577$ \\
\hline $\mathrm{DCE}(\mathrm{Pt})$ & $E_{P}^{R}=0.357 \sigma_{\mathrm{x}}-1.889$ & $E_{P}^{O}=-0.562 \sigma_{\mathrm{x}}+1.574$ \\
\hline $\mathrm{DCE}(\mathrm{GC})$ & $E_{P}^{R}=0.419 \sigma_{\mathrm{x}}-2.176$ & $E_{P}^{O}=-0.424 \sigma_{\mathrm{x}}+1.563$ \\
\hline $\mathrm{DCE}(\mathrm{Au})$ & $E_{P}^{R}=0.125 \sigma_{\mathrm{x}}-1.853$ & $E_{P}^{O}=-0.330 \sigma_{\mathrm{x}}+1.437$ \\
\hline $\mathrm{AN}(\mathrm{Pt})$ & $E_{P}^{R}=0.14 \sigma_{\mathrm{x}}-1.741$ & $E_{P}^{O}=-0.406 \sigma_{\mathrm{x}}+1.394$ \\
\hline $\mathrm{AN}(\mathrm{GC})$ & $E_{P}^{R}=0.438 \sigma_{\mathrm{x}}-2.205$ & $E_{P}^{O}=-0.395 \sigma_{\mathrm{x}}+1.376$ \\
\hline $\mathrm{AN}(\mathrm{Au})$ & $E_{P}^{R}=0.387 \sigma_{\mathrm{x}}-2.182$ & $E_{P}^{O}=-0.259 \sigma_{\mathrm{x}}+1.503$ \\
\hline
\end{tabular}

\section{CONCLUSION}

An electrochemical study, related to the redox characteristics of some substituted chromene la-e in nonaqueous solvents, has been performed using cyclic voltammetry. The redox mechanism is suggested and proved. All compounds are oxidized in a single irreversible one electron process following EC-mechanism to give a dimmer. They are reduced in a single irreversible two electrons step gives dianion, which abstract two protons from the media to saturate the $(-\mathrm{C}=\mathrm{O})$ bond.

\section{ACKNOWLEDGEMENTS}

The author gratefully acknowledge the spirits of Prof. Dr. Z.E. Kandeal, Chemistry Department, Faculty of Science, Cairo University who provided me with the organic compounds. Also I acknowledge Micro Analytical Center, Faculty of Science, Cairo University where the analysis for the products of CPO experiment were proceed

\section{REFERENCES}

[1] El Maghraby, A.A.; Abou-Elenien, G.M.; Shehata, K.I. Study of the electrochemihcal redox characteristics of some triazolopyrimidines.; J.Korean Elctrochem. Soc., 2007, 10(3), 159.

[2] El Maghraby, A.A.; Abou-Elenien, G.M.; Abdel Reheem, N.A.; Abdel Tawab, H.R. Electrochemical Studies on some substituted Thiadiazoles. J. Korean Chem. Soc., 2006, 50(4), 307.

[3] Abou-Elenien, G.M.; El-Maghraby, A.A.; Abdel-Tawab, H.R Voltammetric studies on some azoles and their derivatives. Electroanalysis, 2001, 13(7), 587.

[4] Abou-Elenien, G.M.:Ismail, N.A.; El Maghraby, A.A.; AlAbdallah, G.M. Electrochemical studies on some pyrazole, oxadiazole and thiadiazole derivatives Electroanalysis, 2001, 13(12), 1022.

[5] Abou-Elenien, G.M.; Abelhamide, A.O.; Ismail,N.A.; ElMaghraby,A.A.; El-Hamadi, M.A.I. Electrochemical behaviour of some substituted thiadiazoles. Electrochemistry, 2001, 69(9), 652.

[6] Abou-Elenien, G.M.; Ismail, N.A.; El-Maghraby, A.A.; El-Hamadi, M.A.I. Solvent effect on the redox characteristics of different thiadiazoles in nonaqueous media. Electroanalysis, 2002, 14(4), 998.

[7] Abou-Elenien, G.M. Solvent effect on the redox characteristics of different hydrazyls in nonaqueous media. J. Electroanal. Chem., 1993, 345, 303.

[8] Cauquis, G.; Fahmy, H.M.; Pierre, G.; Elnagdi, M.H. Electrochemical oxidation of substituted Thiazoles:2-amino-4ethyoxycarbonyl-5-methylthiazole and N-ethoxycarbonyl-N'-(4ethoxycarbonyl-5-methylthiazol-2-YL)Thiourea. Electrochim. Acta, 1979, 24, 391.

[9] Sherman, E.O.; Lambert, Jr.S.M.; Pilgram, K. Polarography of some 2,1,3-Benzothiadiazoles, Benzofurazans,2,1,3-Benzoselenadiazoles,and 3,4-Disubstituted and Fused 1,2,5-Thiadiazoles. $J$. Heterocycl. Chem., 1974, 11, 763.

[10] Kandeel, Z.E.; Farag, A.M.; Shaaban, M.R.; Elnagdi, M.H. Sudies with 1,3-Diketones.;A convenient synthesis of some tetrahydro-4H- 
benzopyran and tetrahydroquinone derivatives. Heteratom Chem., 1996, 7, 35 .

[11] Walter, M.; Ramaley, L. Purification of Acetonitrile. Anal. Chem., 1973, 45, 165 .

[12] Abou-Elenien, G.M.; Ph. D. Thesis, Freiburg, Germany, 1980.

[13] Surov, I.; Lund, H. Electrochemical reduction of isoxazoles and related compounds. Acta Chem. Second B, 1986, 40, 831 .

[14] Janz, G.J.; Tomkins, R.P.T. Nonaqueous electrolytes hand book, chapter VI, organic electrolyte. Academic press, Inc. 1973, Vol. II, $\mathrm{p}, 352$.

[15] Sawyer, D.T.; Komai, R.Y. Elctrochemistry of phenazine at platinum electrode in aprotic solvents. Anal. Chem., 1972, 44,715.

[16] Abou-Elenien, G.M.; Ismail, N.A.; Hassnin, M.M.; Fahmy,A.A. Elcrochemical studies on arylhydrazomesoxalonitriles in nonaqueous media. Can. J. Chem., 1992, 70, 2704.

[17] Abou-Elenien, G.M. Redox characteristics of some substituted formazans in aqueous media. J. Elelctroanal. Chem., 1994, 375, 301 .

[18] Abou-Elenien, G.M.; Ismail, N.A.; Elmaghraby, A.A. Voltammetric studies on substituted 2-Arylazoanthraquinones in non-aqueous medium. Electrochim. Acta, 1991, 36, 927.
[19] Smith, W.H.; Bard, A.J. Electrochemical reactions of orgrnic compounds in liquid ammonia.II.Nitrobenzene and Nitrosobenzene. $J$. Amer. Chem. Soc., 1975, 97, 5203.

[20] Mendkovich, A.; Michalchenko, L.V.; Gultyai, V.P. Study of the reactions of 9-Nitroanthracene anion radicals and dianions in dimethylformamide by the controlled potential constant- voltage electrolysis methode. J.Electroanal. Chem. 1987, 224, 273.

[21] Gutmann,V.; Heinz, C. Polarographic investigations in nitrobenzene. Chem. Anal. (Warsaw) 1972, 17(3), 731.

[22] Jaffe, H. H.; A reexamination of the Hammet equation. Chem.Rev., 1953, 53, 191.

[23] Abou-Elenien, G.M.; El-Anadouli,B.E.; Baraka,R.M. Anodic oxidation of some substituted benzoylacetanilides in non-aqueous media. J. Chem. Soc. Perkin Trans., 1991, 2, 1377.

[24] Abou-Elenien, G.M.; El-Anadouli, B.E.; Baraka, R.M. Elecroreduction of benzylacetanilides in no- aqueous medium. Electroanalysis, 1994, 6, 515.

[25] Gutmann, V. Electron dynamics of chemical reciprocal effect. Monatsh. Chem., 1973, 104, 990.

(C) A.A. El Maghraby; Licensee Bentham Open.

This is an open access article licensed under the terms of the Creative Commons Attribution Non-Commercial License (http: //creativecommons.org/licenses/by$\mathrm{nc} / 3.0 /$ ) which permits unrestricted, non-commercial use, distribution and reproduction in any medium, provided the work is properly cited. 